\title{
PKC $\alpha$ induces differentiation through ERK1/2 phosphorylation in mouse keratinocytes
}

\author{
Haeng Ran Seo ${ }^{1, *}$, Yoo-Wook Kwan ${ }^{2, *}$, \\ Chul-Koo Cho', Sangwoo Bae ${ }^{1}$, \\ Su-Jae Lee ${ }^{1}$, Jae-Won Soh ${ }^{3}$, \\ Hee-Yong Chung ${ }^{4}$ and Yun-Sil Lee $e^{1,5}$ \\ ${ }^{1}$ Laboratory of Radiation Effect \\ Korea Institute of Radiological and \\ Medical Sciences, 215-4 Gongneung-dong \\ Nowon-Ku, Seoul 139-706, Korea \\ ${ }^{2}$ Laboratory of Immunopathology \\ NIADI, NIH, Rockville, USA \\ ${ }^{3}$ Department of Chemistry \\ Inha University, Incheon 402-751, Korea \\ ${ }^{4}$ Department of Microbiology \\ College of Medicine, Hanyang University \\ Seoul 133-791, Korea \\ ${ }^{5}$ Corresponding authors: Tel, 82-2-970-1325; \\ Fax, 82-2-977-0381; E-mail, yslee@kcch.re.kr \\ *These authors contributed equally to this work.
}

\section{Accepted 21 May 2004}

Abbreviations: DAG, diacyglycerol; ERK, extracellular signal-regulated kinase; JNK, c-JUN N-terminal kinase; MAPK, mitogenactivated protein kinase; PBS, phosphate buffered saline; PKC, protein kinase $\mathrm{C}$

\begin{abstract}
Epidermal keratinocyte differentiation is a tightly regulated stepwise process that requires protein kinase $C$ (PKC) activation. Studies on cultured mouse keraitnocytes induced to differentiate with $\mathrm{Ca}^{2+}$ have indirectly implicated the involve. ment of PKC $\alpha$ is oform. When PKC $\alpha$ was overexpressed in undifferentiated keratinocytes us. ing adenoviral system, expressions of differentiation markers such as loricrin, filaggrin, keratin 1 (MK1) and keratin 10 (MK10) were increased, and ERK $1 / 2$ phosphorylation was con. currently induced without change of other MAPK such as p38 MAPK and JNK1/2. Similarly, transfection of $P K C \alpha$ kinase active mutant $(P K C \alpha-$ CAT) in the undifferentiated keratinocyte, but not PKC $\beta-C A T$, also increased differentiation marker expressions. On the other hand, $\mathrm{PKC} \alpha$ dominant negative mutant (PKC $\beta-K R$ ) reduced
\end{abstract}

$\mathrm{Ca}^{2+}$-mediated differentiation marker expressions, while PKC $\beta-K R$ did not, suggesting that PKC $\alpha$ is responsible for keratinocyte differentiation. When downstream pathway of $\mathrm{PKC} \alpha$ in $\mathrm{Ca}^{2+}$. mediated differentiation was examined, ERK1/2, p38 MAPK and JNK1/2 phosphorylations were increased by $\mathrm{Ca}^{2+}$ shift. Treatment of keratinocytes with PD98059, MEK inhibitor, and SB20358, p38 MAPK inhibitor, before $\mathrm{Ca}^{2+}$ shift induced morphological changes and reduced expres. sions of differentiation markers, but treatment with SP60012, JNK1/2 inhibitor, did not change at all. Dominant negative mutants of ERK1/2 and p38 MAPK also inhibited the expressions of differentiation marker expressions in $\mathrm{Ca}^{2+}$ shifted cells. The above results indicate that both ERK1/2 and $\mathrm{p} 38$ MAPK may be involved in $\mathrm{Ca}^{2+}$. mediated differentiation, and that only ERK1/2 pathway is specific for PKC $\alpha$-mediated differentiation in mouse keratinocytes.

Keywords: $\mathrm{Ca}^{2+}$-mediated differentiation; ERK1/2; mouse keratinocytes; p38 MAPK; PKC $\alpha$

\section{Introduction}

Keratinocytes provide an excellent in vitro model for the study of normal cell differentiation (Green et al., 1977; Eckert, 1989). Keratinocytes, the normal epidermis progress through four phenotypic stages as they migrate from the basement membrane to the surface of the skin. Specific markers of differentiation have been identified, including spinous cell keratin (MK) 1 and 10, granular cell proteins filaggrin, loricrin, and SPR-1, and transglutaminases TGK and TGE (Rice et al., 1992; Fuchs et al., 1994; Kartasova et al., 1996; Kim et al., 1996; Kim and Bae, 1998). Earlier reports suggest that activation of PKC regulates the expression of genes involved in the terminal stages of epidermal differentiation (Yuspa et al., 1990; Dlugosz et al., 1994; Dlugosz et al., 1994). When keratinocytes are grown at calcium concentration below $0.05 \mathrm{mM}$, they continue to proliferate by either failure or slow development of intercellular contacts, stratify little if at all, and fail or are slow to form cornified envelopes.

In cultured keratinocytes, elevation of extracellular $\mathrm{Ca}^{2+}$ concentration increases phosphatidylinositol turn- 
over, resulting in increased DAG levels in keratinocytes (Jaken et al., 1988; Punnonen et al., 1993; Tang et al., 1993; Min DS et al., 2002), and induces phosphorylation of a subset of proteins, similar to pharmacological PKC activator 12-0-tetradecanoylphorbol-13-acetate (TPA) (Wirth et al., 1987). Activation of PKC by TPA or DAG stimulates cornified envelope formation (Lichti et al., 1988) and causes the transition of spinous expression to granular layer differentiation markers: the expression of filaggrin and loricrin is induced, whereas the expression of MK1 and MK10 is suppressed (Yuspa et al., 1983). Although PKC activation can not explain all of the effects of calcium on keratinocyte differentiation, it appears to clearly play a major role. However, the study of PKC in differentiation is complicated due to the large number of PKC isozymes $(\alpha, \delta, \varepsilon, \eta$ and $\zeta)$. Sudden increase of the exracellular calcium concentration above $0.12 \mathrm{mM}$ leads to a number of acute changes, including redistribution of protein kinase $\mathrm{C} \alpha(\mathrm{PKC} \alpha)$ to the membrane (Sheu et al., 1989; Denning et al., 1995) at least in mouse keratinocytes, and PKC $\alpha$ antisense treatment inhibits $\mathrm{Ca}^{2+}$ mediated keratinocytes differentiations (Lee et al., 1997). However, the mechanism by which extracelluar free $\mathrm{Ca}^{2+}$ triggers differentiation is not well understood.

In the present study, we observed that PKC $\alpha$ was involved in $\mathrm{Ca}^{2+}$-mediated keratinocyte differentiation through ERK1/2 phosphorylation in mouse system.

\section{Materials and Methods}

\section{Cell culture}

Primary mouse epidermal keratinocytes were isolated from BALB/c mice and were grown in Eagle's minimal essential medium with $8 \%$ Chelex-treated fetal calf serum, $0.2 \%$ penicillin/streptomycin solution (Gibco, BRL, Gaithersburg, MD), and $0.05 \mathrm{mM} \mathrm{Ca}^{2+}$ to maintain a basal cell-like population of undifferentiated cells (Henning et al., 1980). To induce terminal differentiation, $\mathrm{CaCl}_{2}$ was added directly to culture media.

\section{Chemicals and antibodies}

PD98059 (inhibitor of MEK) and SB203580 (inhibitor of p38 MAPK) were purchased from Calbiochem (La Jolla, CA) and SP600125 (inhibitor of JNK) was from TOCRIS (Ballwin, MO). Anti-PKC $\alpha,-\beta,-\delta$ and anti- $\beta$-tublin antibodies were purchased from Santa Cruz Biotechnology (Santa Cruz, CA) and anti-MAPK, anti-phospho-MAPK (P202/Y204), anti-JNK, anti-phospho-JNK1/2, anti-p38 MAPK and anti-phospho-p38 MAPK polyclonal antibodies were from New England BioLabs (Beverly, MA). The keratinocyte markers MK1, MK10, MK14, loricrin, and filaggrin were from
Babco (Richmond, CA).

\section{Vector construction}

MFG retroviral vector by replacing the GFP sequence of MFG.GFP.IRES.puro (Park et al., 2000) was used for gene transfection. The MFG.GFP.IRES.puro itself was used as a negative control throughout the experiment. The retroviral plasmids were introduced into 293gpg retrovirus packaging cell line by transient transfection with Lipofectamine (Gibco/BRL). After 72 $h$, the supernatants were harvested and used for retroviral infection. The virus titers, measured in NIH3T3 cell line by puromycin-resistant colony formation, were between $10^{5}$ and $5 \times 10^{5} / \mathrm{ml}$. The infection and selection of the target cells by puromycin were performed as described previously (Ory et al., 1996). PKC-KR expression MFGpuro retroviral vectors were generated by ligating full length open reading frames of PKC isoforms with a $\mathrm{K} \rightarrow \mathrm{R}$ point mutation at the ATP binding site. PKC-CAT expression MFGpuro retroviral vectors were generated by ligating cDNA fragments encoding only the CAT domain of isoforms. All the CDNA fragments of PKC mutants were generated by PCR and were analyzed to confirm their sequences with an automated DNA sequencer (Lee et al., 2002). The eukaryotic expression vectors, rat ERK2-KR, under the control of the cytomegalovirus promoter were produced by cloning the inserts from the respective NpT7-5 clones into pCMV5 (Kortenjann et al., 1994). The catalytically inactive dominant-negative JNK-2 (Lee et al., 2003) was amplified with sense (5'-aaaatctagactgccatggcatacccatacgacgtcc-3') and anti-sense (5'-aaaaggatcctcatcgacagccttaagg-3') primers using High fidelity taq polymerase (GIBCO/ $\mathrm{BRL})$. The PCR products were digested with Nco-1 and $B a m H 1$ restriction enzymes, and cloned into the corresponding sites in the MFG retroviral vector by replacing the GFP sequence of MFG.GFP.IRES.puro. Adenovirus mediated $\mathrm{PKC} \alpha$ and $-\delta$ were kindly donated by Dr. T. Kuroki (Ohba et al., 1998). The infection of adenovirus was carried out in serum-free medium containing $2.5 \mathrm{mg}$ of polybrene (Sigma, St. Louis, MO) per $\mathrm{ml}$ at $50 \mathrm{PFU} /$ cell for BCE cells for $30 \mathrm{~min}$ at room temperature. Fresh serum containing medium was added thereafter. Adenoviral-CMV- $\beta$-gal was generated by the method described previously (Park et al., 2003).

\section{Polyacrylamide gel electrophoresis and Western blot}

The cells were washed twice with ice-cold PBS, scraped into SDS sample buffer, boiled, and run immediately on $8.5 \%$ polyacrylamide gels. Proteins were transferred electrophoretically to nitrocellulose, and the membranes were blocked in $5 \%$ milk. For 
detection of PKC isozymes, the membranes were incubated with specific antibodies. Proteins were detected with horseradish peroxidase-conjugated secondary antibody (Bio-Rad, Hercules, CA), and specific bands were visualized by chemiluminescence $(E C L$, Amersham International). Autoradiographs were recorded onto X-Omat AR films (Eastman Kodak Co.).

\section{Results}

\section{$\mathrm{Ca}^{2+}$ shift to $0.12 \mathrm{mM}$ induced differentiation in mouse keratinocytes}

Healthy mouse keratinocytes culture in medium containing low $\mathrm{Ca}^{2+}(0.05 \mathrm{mM})$ proliferate and express basal keratinocyte markers. However, the cells can be induced to differentiate by elevating the $\mathrm{Ca}^{2+}$ concentration above $0.1 \mathrm{mM}$ (Figure $1 \mathrm{~A}$ ), and differentiation markers, including loricrin, filaggrin, and MK10, also increased $48 \mathrm{~h}$ after the $\mathrm{Ca}^{2+}$ shift (Figure 1B).

\section{PKC $\alpha$ activation was responsible for phosphorylation of ERK1/2 and JNK1/2, as well as differentiation markers}

Earlier reports suggested that PKC $\alpha$ is a key molecule involved in $\mathrm{Ca}^{2+}$ mediated differentiation. To elucidate the relationship between $\mathrm{PKC} \alpha$ activation and induction of differentiation, adenoviral PKC $\alpha$ was overexpressed in mouse keratinocytes. PKC $\delta$ using adenoviral vector in low $\mathrm{Ca}^{2+}$ media was also transfected to compare functions of $\mathrm{PKC} \alpha$ and $\mathrm{PKC} \delta$ in keratinocyte differentiation. Adenoviral PKC $\alpha$ or PKC $\delta$ overexpression induced increased kinase activity (Figure $2 \mathrm{~B}$ ) as well as protein level (Figure 2A) of both PKC $\alpha$ and PKC $\delta$. Downstream activation by $P K C \alpha$ overespression is phospho-ERK1/2, while the level of this protein phosphorylations was not changed in the case of PKC $\delta$. When downstream pathways were examined, PKC $\alpha$ activation induced phospho-ERK1/2 and phospho-JNK1/2 expressions, while p38 phosphorylation was not changed. When PKC $\delta$ was overexpressed, no difference in phosphorylations of ERK1/2, p38 MAPK, and JNK1/2 was found (Figure 2C). When differentiation marker expressions were also examined, PKC $\alpha$ overexpression induced MK1, MK10, filaggrin and loricrin, similar to the level of high $\mathrm{Ca}^{2+}$ shift. The observation that $\mathrm{PKC} \delta$ overexpression slightly affected the late maker expressions such as loricrin and filaggrin, but not the early differentiation markers, suggests a possibility of PKC $\alpha$ involvement in late differentiation marker regulation (Figure 2D). Similar result was obtained, when using retroviral catalytic active PKC $\alpha$ vector (CAT-PKC $\alpha$ ) in low $\mathrm{Ca}^{2+}$ media (Figure 3B). When dominant negative $\mathrm{PKC} \alpha$ $(P K C \alpha-K R)$ was transfected, the expression of differ- entiation markers by high $\mathrm{Ca}^{2+}$ media was blocked, while PKC $\beta-K R$ did not affect $\mathrm{Ca}^{2+}$-mediated differentiation (Figure $3 C$ ).

\section{$\mathrm{Ca}^{2+}$ shift to $0.12 \mathrm{mM}$ induced ERK1/2, p38 and JNK phosphorylation}

To elucidate the mechanism of $\mathrm{Ca}^{2+}$ mediated differentiation, phosphorylation of ERK1/2, p38 MAPK, and JNK1/2 was examined. As shown in Figure 4, ERK1/2 activation was bi-phasic at $30 \mathrm{~min}$ and $24 \mathrm{~h}$ after $\mathrm{Ca}^{2+}$ shift, and peak activation was at $24 \mathrm{~h}$ after the $\mathrm{Ca}^{2+}$ shift. In the case of p38 MAPK and JNK1/2, phosphorylation was increased from $15 \mathrm{~min}$ after $\mathrm{Ca}^{2+}$ shift and they lasted until $48 \mathrm{~h}$.

\section{ERK1/2 activation is responsible for $\mathrm{Ca}^{2+}$-mediated differentiation}

To elucidate downstream pathway of $\mathrm{Ca}^{2+}$-mediated differentiation, PD98059 (MEK1/2 inhibitor), SB203580 (p38 MAPK inhibitor) and SP600125 (JNK1/2 inhibitor)

A

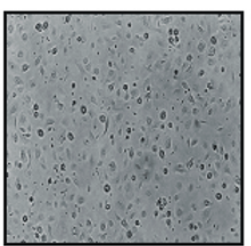

Low $\mathrm{Ca}^{+2}$

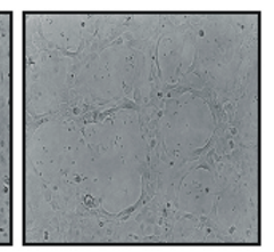

High $\mathrm{Ca}^{+2}$
B (min) (h) 015306036122448

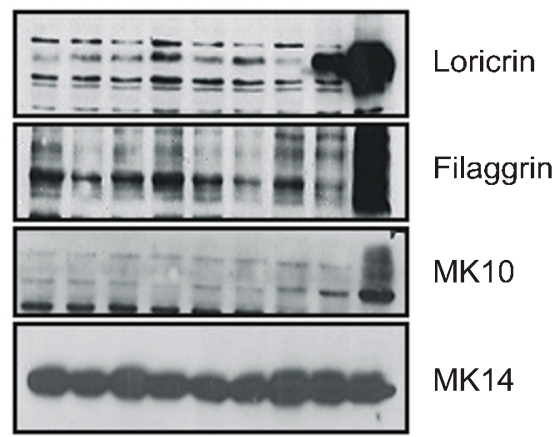

Figure 1. Cellular morphology in $0.12 \mathrm{mM} \mathrm{Ca}^{2+}$ shifted normal keratinocytes. (A) Primary mouse keratinocytes were grown in media containing $0.05 \mathrm{mM} \mathrm{Ca}^{2+}$ concentration, and then switched to 0.12 $\mathrm{mM} \mathrm{Ca}{ }^{2+}$-containing media. After $48 \mathrm{~h}$, photomicrographs were examined. (B) At indicated times of $0.12 \mathrm{mM} \mathrm{Ca}^{2+}$ shift, whole SDS lysates were prepared, and protein samples were subjected to PAGE and transferred to nitrocellulose membranes, and keratinocyte marker proteins were detected with specific antibodies. The results represent one of three independent experiments. 
A

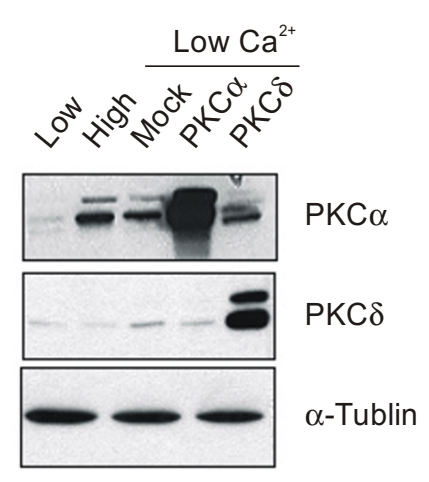

B

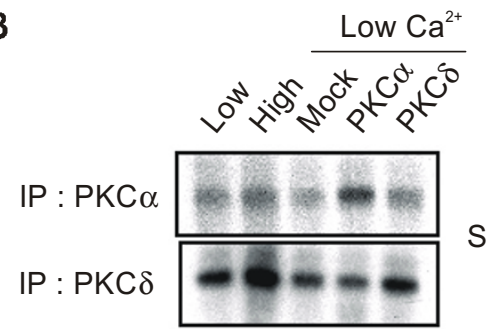

C

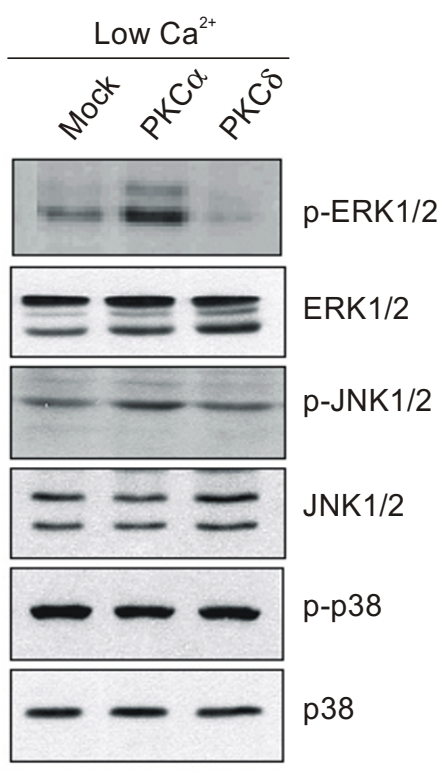

D

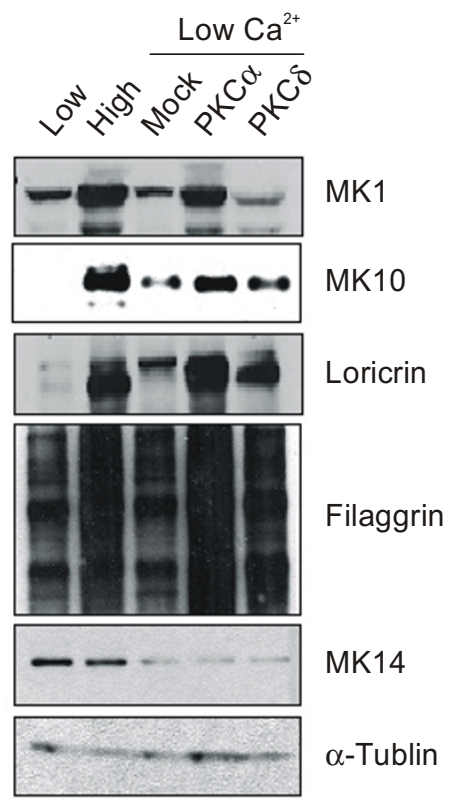

Figure 2. PKC $\alpha$ overepxression in $0.05 \mathrm{mM} \mathrm{Ca}^{{ }^{4}}$ induced ERK1/2 phosphorylation and differentiation marker expressions. (A, C) Primary mouse keratinocytes were grown in media containing $0.05 \mathrm{mM} \mathrm{Ca}^{2+}$ concentration, and then adenoviral vectors of PKC $\alpha-\beta$ and control $\beta$-gal were transfected. At $24 \mathrm{~h}$ of transfection, protein lysis were prepared, subjected to PAGE and Western blotting. (B) Cellular proteins were extracted by lysis with PKC extraction buffer. Proteins from $300 \mu \mathrm{g}$ of cell extracts were immunoprecipitated by using an anti-PKC antibody and protein G-Sepharose. Immune complex kinase reactions were performed in the presence of GST-MARCKS substrate and [ $\gamma^{32}$ P]ATP. The results represent one of three independent experiments. (D) Whole SDS lysates were prepared, protein samples subjected to PAGE and transferred to nitrocellulose membranes, and keratinocyte marker proteins were detected with specific antibodies. The results represent one of three independent experiments.

were applied at 30 min before $\mathrm{Ca}^{2+}$-shift. As seen in Figure $5 \mathrm{~A}$, morphological changes indicated that pretreatment of the cells with PD98059 and SB203480 blocked $\mathrm{Ca}^{2+}$-medaited differentiation, the effect being more prominent in SB203580 pretreated cells, while, $\mathrm{Ca}^{2+}$-mediated differentiation was not changed in the case of SP600125 pretreated cells (Figure 5A). When differentiation markers were examined, PD98059 and SB203580 blocked both early differentiation (MK1 and MK10) and late differentiation (loricrin and filaggrin) marker expressions, while SP600125 pretreatment did not change $\mathrm{Ca}^{2+}$-mediated differentiation marker expressions (Figure 5B). We further confirmed differentiation marker expressions using dominant-negative mutants of ERK1 (ERK1-KR), JNK1 (JNK1-KR) and p38 MAPK (p38-KR). Similar to the effects of pharmacological drugs, ERK1-KR and p38-KR blocked $\mathrm{Ca}^{2+}$ mediated differentiation marker expressions, while no difference was shown in the case of JNK1-KR (Figure $5 C)$.

\section{Discussion}

The existence of multiple PKC isozymes, having distinct cofactor requirements, tissue distribution, and substrate specificities, suggests that the individual PKC isozymes have specific roles in cellular physiology. The role of PKC in keratinocyte differentiation is well established (Hawley-Nelson et al., 1982; Yuspa et al., 1982; Dlugosz et al., 1993). Although PKC activation can induce differentiation at low calcium concentrations, its effects are potentiated by calcium (Yuspa et al., 1983). Five PKC isozymes have been identified in mouse (Dlugosz et al., 1992) and human keratinocytes (Fisher et al., 1993; Reynolds et al., 1994), and only one of the five, PKC $\alpha$, is activated by calcium. In the mouse keratinocytes, PKC $\alpha$ has been implicated in the induction of the late differentiation markers by calcium (Denning et al., 1995; Lee et al., 1997). Studies using pharmacological PKC inhibitors (Lee et al., 1998) and PKC $\alpha$ antisense oligonucleotides (Lee et al., 1997) have suggested that PKC $\alpha$ activation regulates the granular cell stage 
A

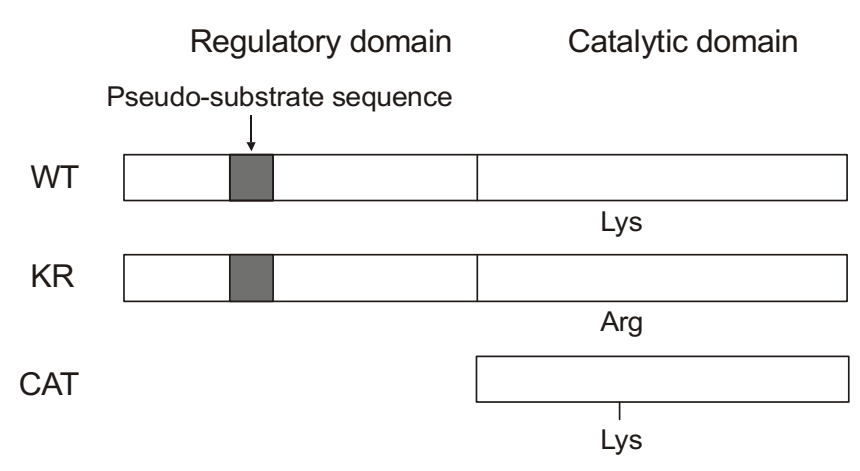

B

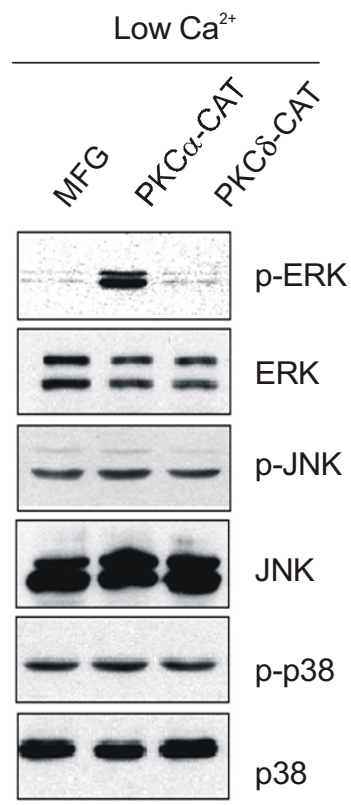

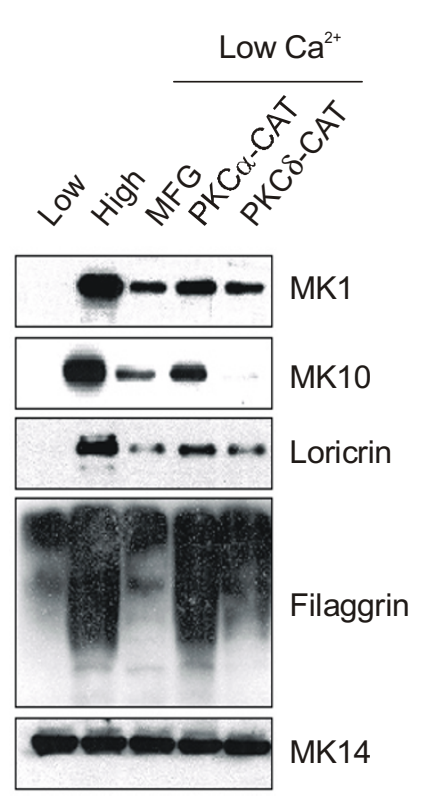

C

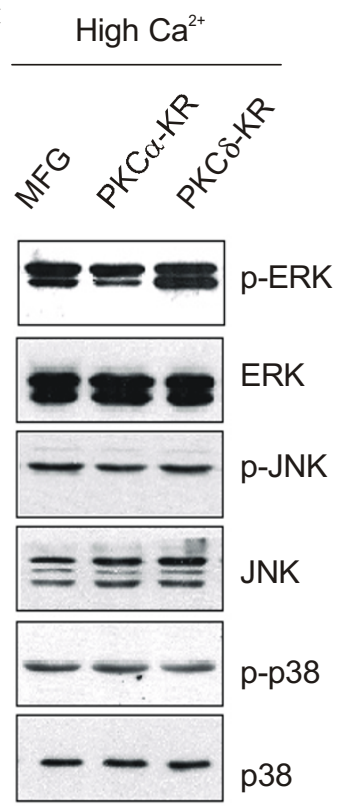

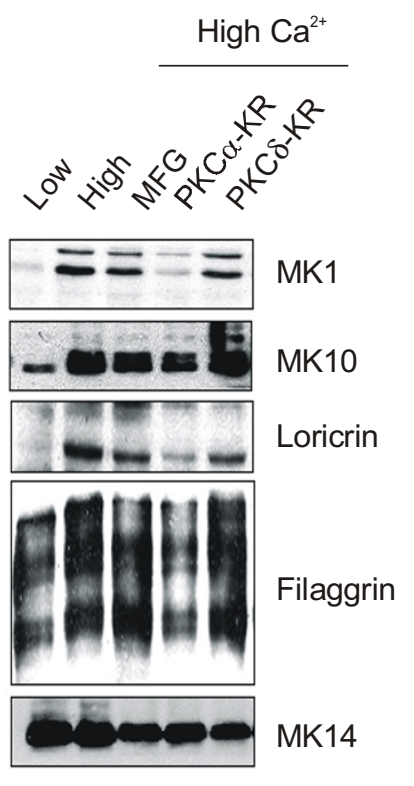

Figure 3. PKC $\alpha-C A T$ in $0.05 \mathrm{mM} \mathrm{Ca}^{2+}$ induced ERK1/2 phosphorylation and differentiation marker expressions, but PKC $\alpha-\mathrm{KR}^{2}$ in $0.12 \mathrm{mM} C \mathrm{a}^{2+}$ inhibited. Control vector (MFG) and kinase active types of PKC $\alpha$ and PKC $\beta$ (PKC $\alpha-C A T$ and PKC $\beta-C A T)$ in $0.05 \mathrm{mM} \mathrm{Ca}^{2+}$ media (A) or dominant negative mutants of PKC $\alpha$ and PKC $\beta$ (PKC $\alpha-K R$ and PKC $\beta-K R$ ) in $0.12 \mathrm{mM} \mathrm{Ca}^{2+}$ (B) were transfected and after $24 \mathrm{~h}$, whole SDS lysates were prepared, protein samples subjected to PAGE and Western blotting. The results represent one of three independent experiments.

of epidermal differentiation by enhancing expression of loricrin, profilaggrin, and TGk mRNA. In the present study, we more addressed this issue rigorously by overexpression of $\mathrm{PKC} \alpha$ using adenoviral and retroviral vector system.

When $\mathrm{Ca}^{2+}$ was shifted to $0.12 \mathrm{mM}$, the expressions of keratinocyte differentiation markers such as loricrin, filaggrin and MK10 were induced from $24 \mathrm{~h}$ of $\mathrm{Ca}^{2+}$-shift and peaked at $48 \mathrm{~h}$, while the expression of basal cell marker MK14 was unaffected. Morphological changes also indicated that $0.12 \mathrm{mM} \mathrm{Ca}^{2+}$ induced differentiation in mouse keratinocytes, compared to the cells in low- $\mathrm{Ca}^{2+}$ media (Figure 1). Furthermore, direct correlation between $\mathrm{PKC} \alpha$ and keratinocyte differentiation was examined: When $\mathrm{PKC} \alpha$ or $-\delta$ was overexpressed, both $\mathrm{PKC} \alpha$ and $-\delta$ kinase activities were increased, suggesting that both PKC isozymes were activated in both PKC isozyme overexpression systems. However, keratinocyte differentiation markers were expressed only in $\mathrm{PKC} \alpha$ overexpressed cells, but not in PKC $\delta$ overexpressed cells, indicating that $P K C \alpha$ is essential for keratinocyte differentiation. Similar effects were also observed when catalytic active PKC $\alpha$ retroviral vector was overexpressed (Figure 2). Reversely, transfection of dominant negative $\mathrm{PKC} \alpha(\mathrm{PKC} \alpha-\mathrm{KR})$ in high $\mathrm{Ca}^{2+}$ media inhibited differentiation, further indicating that $\mathrm{PKC} \alpha$ is essential for keratinocyte differentiation. When PKC $\alpha$ downstream molecules such as ERK1/2, JNK1/2 and p38 MAPK were studied, ERK1/2 phosphorylation was found to have changed by $P K C \alpha$; adenoviral PKC $\alpha$ and PKC $\alpha-C A T$ increased and 
(min)

(h)

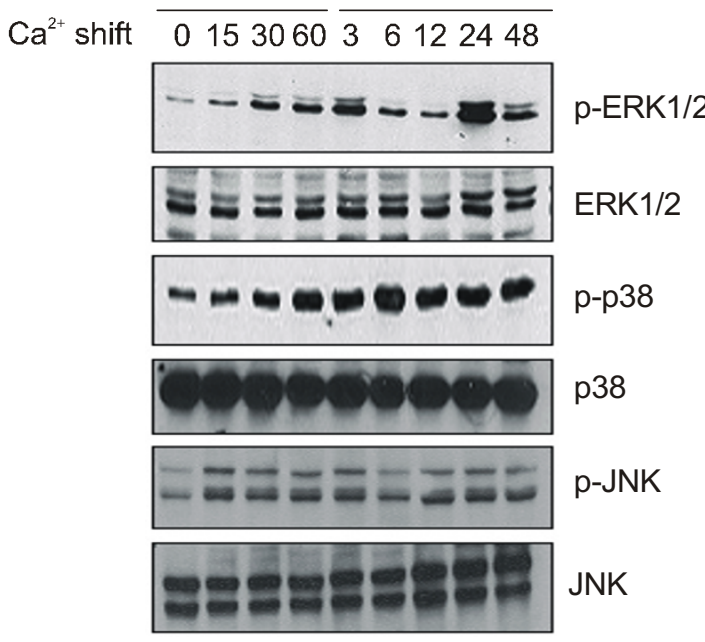

Figure 4. $\mathrm{Ca}^{2+}$ shift increased MAPK phosphorylation. Primary mouse keratinocytes were grown in media of $0.05 \mathrm{mM} \mathrm{Ca}{ }^{2+}$ concentration, and then switched to $0.12 \mathrm{mM} \mathrm{Ca}^{2+}$-containing media. At indicated times of $0.12 \mathrm{mM} \mathrm{Ca}^{2+}$ shift, protein lysates were prepared, subjected to PAGE and Western blotting. The results represent one of three independent experiments.
PKC $\alpha-K R$ reduced ERK1/2 phosphorylation, suggesting ERK1/2 phosphorylation as PKC $\alpha$ downstream in keratinocyte differentiation.

Since phosphorylation of ERK1/2, JNK1/2 and p38 MAPK was increased after $\mathrm{Ca}^{2+}$ shift (Figure 4), employing inhibitors of ERK1/2, p38 MAPK, and JNK1/2, we examined morphological changes with inhibition of differentiation marker expressions after $\mathrm{Ca}^{2+}$ shift, and observed that PD98059 and SB203580, the morphological changes while SP 600125 potentiated, suggesting that ERK $1 / 2$ and p38 MAPK may be involved in $\mathrm{Ca}^{2+}$-mediated differentiation (Figure 5). In our data, ERK1/2 phosphorylation was increased in biphasic pattern. We do not know exactly how biphsic expression of phopho-ERK1/2 was regulated in keratinocyte differentiation. However, our preliminary data indicated that both biphasic expression of phospho-ERK1/2 was necessary for keratinocyte differentiation (data not shown) and we are doing further study. When we used dominant negative ERK1/2, JNK1/2 or p38 MAPK to establish direct correlation in $\mathrm{Ca}^{2+}$-mediated differentiation, both dominant negative ERK1/2 and p38 MAPK inhibited differentiation
A

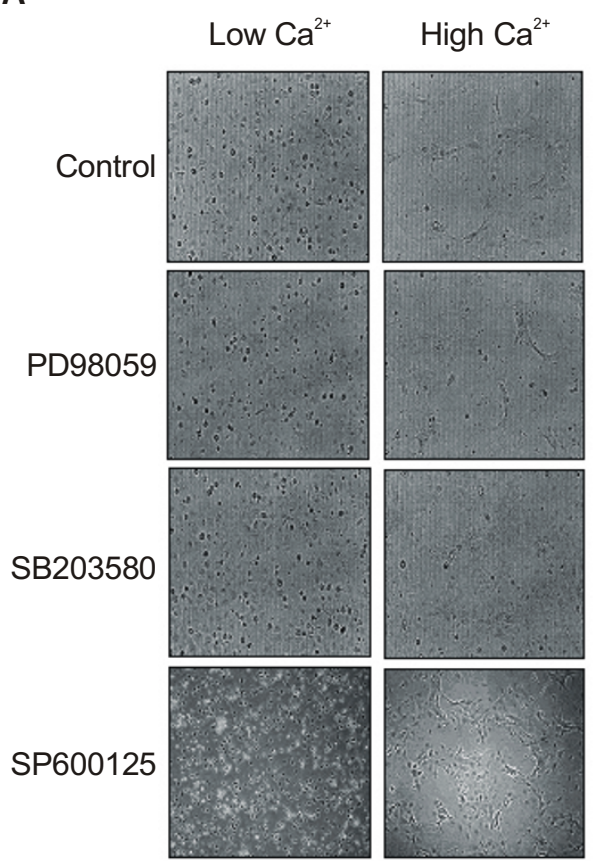

B

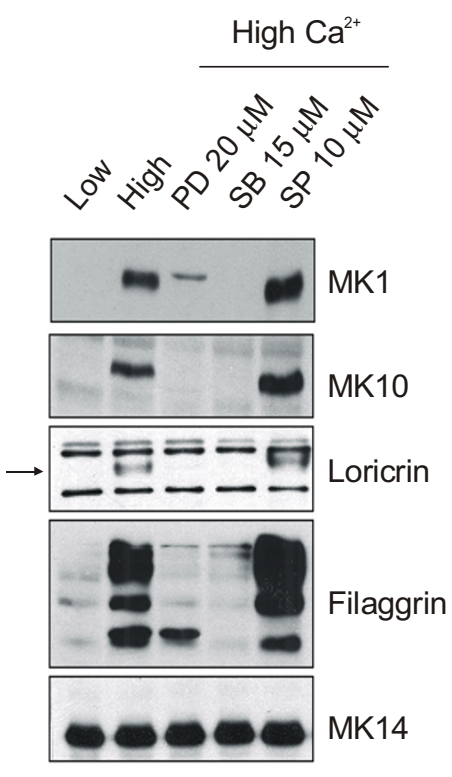

C

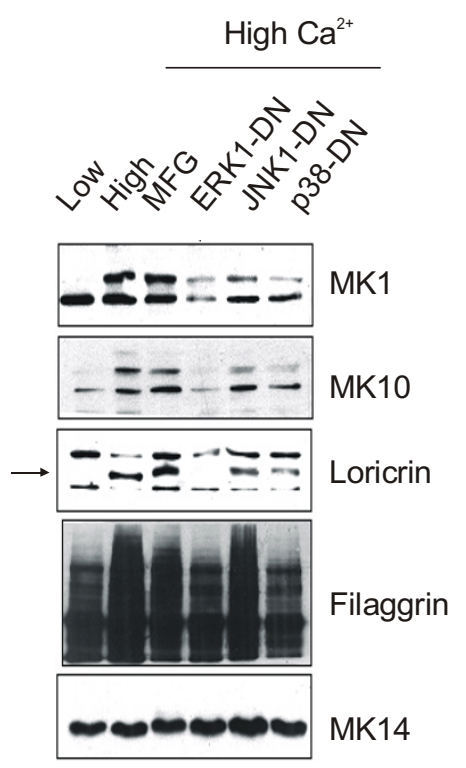

Figure 5. ERK1/2 and P38 MAPK phosphorylation was involved in $\mathrm{Ca}^{L+}$ mediated differentiation. (A) Primary mouse keratinocytes were grown with the media of $0.05 \mathrm{mM} \mathrm{Ca}^{2+}$ concentration, and then switched to $0.12 \mathrm{mM} \mathrm{Ca}^{2+}$-containing media with or without pretreatment of PD98059, SB203580, and SP600125. After $48 \mathrm{~h}$ of $\mathrm{Ca}^{2+}$ shift, photomicrographs were examined. (B) Whole SDS lysates were prepared, protein samples subjected to PAGE and transferred to nitrocellulose membranes, and keratinocyte marker proteins were detected with specific antibodies. (C) Primary mouse keratinocytes were grown with the media of $0.05 \mathrm{mM} \mathrm{Ca}^{2+}$ concentration, and then switched to $0.12 \mathrm{mM} \mathrm{Ca}{ }^{2+}$-containing media with or without transfection of dominant negative mutants of ERK1, p38 MAPK and JNK1 (ERK1-KR, p38-KR and JNK1-KR). After 48 hr of $\mathrm{Ca}^{2+}$ shift, whole SDS lysates were prepared, protein samples subjected to PAGE and transferred to nitrocellulose membranes, and keratinocyte marker proteins were detected with specific antibodies. The results represent one of three independent experiments. 


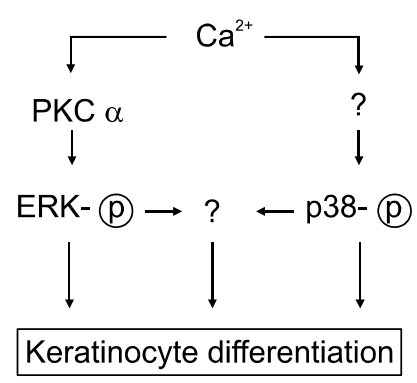

Figure 6. Hypothetical scheme of $\mathrm{Ca}^{{ }^{+}}$mediated differentiation in mouse keratinocytes

marker expression; the effect of ERK1/2 was more prominent. Based on the results, we propose that $\mathrm{Ca}^{2+}$-mediated differentiation marker expression is dependent on both ERK1/2 and p38 MAPK pathways (Figure 6).

Tropical application of TPA on mouse skin increases epidermal thickness accompanied with inflammation: the phenotype similar to psoriatic skin (Furstenberger et al., 1985). Recent studies disclosed that the expression of involucrin and cystatin $A$, two constituents of cornified cell envelope, are regulated by PKC- MAPK pathway (Efimove et al., 1998). Although increased ERK and JNK expressions in psoriatic epidermis was reported (Takahashi et al., 2002) and p38 MAPK is also involved in calcium-induced differentiation (Efimova et al., 2003), the expression and activities of MAPKs in keratinocyte differentiation has not been fully elucidated.

In conclusion, we examined whether $\mathrm{Ca}^{2+}$-mediated differentiation is induced by $\operatorname{PKC} \alpha$ and downstream of $P K C \alpha$ is ERK1/2. In the present study, we could not exclude possible involvement of p38 MAPK pathway, because $\mathrm{Ca}^{2+}$ induced both ERK1/2 and p38 MAPK phosphorylation and inhibition of ERK1/2 and p38 MAPK blocked differentiation marker expression. Nevertheless, since PKC $\alpha$ activation does not directly induce p38 MAPK phosphorylation, another $\mathrm{Ca}^{2+}$ response signaling which may respond to $\mathrm{Ca}^{2+}$ may also be involved in $\mathrm{Ca}^{2+}$-mediated keratinocyte differentiation.

\section{Acknowledgment}

We thank K. J. Kim for his excellent technical assistance. This work was supported by the Nuclear R\&D Program from the Ministry of Science and Technology of Korea.

\section{References}

Denning MF, Dlugosz AA, Williams EK, Szallasi Z, Blumberg $\mathrm{PM}$, Yuspa $\mathrm{SH}$. Specific protein kinase $\mathrm{C}$ isozymes mediated the induction of keratinocyte differentiation markers by calcium. Cell Growth Diff 1995;6:149-57

Dlugosz AA, Mischak H, Mushinski JF, Yuspa SH. Transcripts encoding protein kinase C-alpha, -delta, -epsilon, -zeta and -eta are expressed in basal and differentiating mouse keratinocytes in vitro and exhibit quantitative changes in neoplastic cells. Mol Carcinog 1992;5:286-92

Dlugosz AA, Yuspa SH. Coordinate changes in gene expression which mark the spinous to granular cell transition in epidermis are regulated by protein kinase C. J Cell Biol 1993;120:217-25

Dlugosz AA, Cheng C, Williams EK, Dharia AG, Denning MF, Yuspa SH. Alterations in murine keratinocyte differentiation induced by activated rasHa genes are mediated by protein kinase C-alpha. Cancer Res 1994;54:6413-20

Dlugosz AA, Yuspa SH. Protein kinase $C$ regulates keratinocyte transglutaminase (TGk) gene expression in cultured primary mouse epidermal keratinocytes induced to terminally differentiate by calcium. J Invest Dermatol 1994;102:409-14

Eckert RL. Structure, function, and differentiation of the keratinocyte. Physiol Rev 1989;69:1316-46

Efimova T, LaCelle P, Welter JF, Eckert RL. Regulation of human involuvrin promoter activity by a protein kinase $C$, Ras, MEKK1, MEK3, p38/RK, AP-1 signal transduction pathway. J Biol Chem 1998;273:24387-95

Efimova T, Broome A, Eckert R. A regulatory role fro $\mathrm{p} 38 \delta$ MAPK in keratinocyte differentiation. J Biol Chem 2003;278: 34277-85

Fisher GJ, Tavakkol A, Leach K, Burns D, Basta P, Loomis C, Griffiths CE, Cooper KD, Reynolds NJ, Elder JT. Differential expression of protein kinase $C$ isozymes in normal and psoriatic adult human skin: Reduced expression of protein kinase C-beta II in psoriasis. J Invest Dermatol 1993;101: 553-9

Fuchs E, Byrne C. The epidermis: Rising to the surface. Curr Opin Genet Dev 1994;4:725-36

Furstenberger G, Schweizer J, Marks F. Development of phorbol ester responsiveness in neonatal mouse epidermis: correlation between hyperplastic response and sensitivity to first stage tumor promotion. Carcinogenesis 1985;6:289-94

Green H, Rheinwald JG, Sun TT. Properties of an epithelial cell type in culture: the epidermal keratinocyte and its dependence on products of the fibroblast. Prog Clin Biol Res 1997; $17: 493-500$

Hawley-Nelson P, Stanley JR, Schmidt J, Gullino M, Yuspa $\mathrm{SH}$. The tumor promoter 12-O-tetradecanoylphorbol-13-acetate accelerates keratinocyte differentiation and stimulates growth of an unidentified cell type in cultured human epidermis. Exp Cell Res 1982;137:155-67

Henning $H$, Michael D, Cheng $C$, Steinert P, Holbrook K, Yuspa SH. Calcium regulation of growth and differentiation of mouse epidermal cells in culture. Cell 1980;19:245-54

Jaken S, Yuspa SH. Early signals of keratinocyte differentiation; Role of $\mathrm{Ca}^{2+}$ mediated inositol lipid metabolism in normal and neoplastic epidermal cells. Carcinogenesis 1988; 9:1022-38 
Kartasova T, Darwiche N, Kohno Y, Koizumi H, Osada S, Huh N, Lichti U, Steinert PM, Kuroki T. Sequence and expression patterns of mouse SPR1: Correlation of expression with epithelial function. J Invest Dermatol 1996;106: 294-304

Kim IG, Gorman JJ, Park SC, Chung SI, Steinert PM. The deduced sequence of the novel protransglutaminase $E$ (TGase3) of human and mouse. J Biol Chem 1996;268: 12682-90

Kim SY, Bae CD. Calpain inhibitors reduce the cornified cell envelope formation by inhibiting proteolytic processing of transglutaminase 1. Exp Mol Med 1998;4:257-62

Kortenjann M, Thomae $O$, Shaw PE. Inhibition of $v$-rafdependent $\mathrm{c}$-fos expression and transformation by a kinasedefective mutant of the mitogen-activated protein kinase Erk2. Mol Cell Biol 1994;14:4815-24

Lee YJ, Soh JW, Dean NM, Cho CK, Kim TH, Lee SJ, Lee YS. Protein kinase Cdelta overexpression enhances radiation sensitivity via extracellular regulated protein kinase $1 / 2$ activation, abolishing the radiation-induced $\mathrm{G}(2)-\mathrm{M}$ arrest. Cell Growth Differ 2002;13:237-46

Lee YJ, Cho HN, Soh JW, Jhon GJ, Cho CK, Chung HY, Bae S, Lee SJ, Lee YS. Oxidative stress-induced apoptosis is mediated by ERK $1 / 2$ phosphorylation. Exp Cell Res 2003;291:251-66

Lee YS, Dlugosz AA, McKay R, Dean NM, Yuspa SH. Definition by specific antisense oligonucleotides of a role for protein kinase Calpha in expression of differentiation markers in normal and neoplastic mouse epidermal keratincoytes. Mol Carcinog 1997;18:44-53

Lee YS, Yuspa SH, Dlugosz AA. Differentiation of cultured human epidermal keratinocytes at high cell densities is mediated by endogenous activation of the protein kinase $\mathrm{C}$ signaling pathway. J Invest Dermatol 1998;111:762-6

Lichti U, Yuspa SH. Modulation of tissues and epidermal transglutaminases in mouse epidermal cells after treatment with 12-0-tetradecanylphorbol-13-acetate and/or retinoic acid in vivo and in vulture. Cancer Res 1988;48:74-81

Malmaquist KG, Carlsson LE, Forslind B, Roomans GM, Akselsson KR. Proton and electron microprobe analysis of human skin. Nucl Inst Med Physics Res 1984;3:611-7

Menon GK, Eliam PM. Ultrastructural localization by ioncapture cytochemistry. J Invest Dermatol 1985;84:508-12

Min DS, Shin EY, Kim EG. The p38 mitogen-activated protein kinase is involved in stress induced phospholipase $D$ activation in vasculat smooth muscle cells. Exp Mol Med 2002;34:38-46

Ohba M, Ishino K, Kashiwagi M, Kawabe S, Chida K, Huh $\mathrm{NH}$, Kuroki T. Induction of differentiation in normal human keratinocytes by adenovirus-mediated introduction of the eta and delta isoforms of protein kinase C. Mol Cell Biol 1998; 18:5199-207

Ory DS, Neugeboren BA, Mulligan RC. A stable humanderived packaging cell line for production of high titer retrovirus/vesicular stomatitis virus G pseudotypes. Proc Natl
Acad Sci USA 1996;93:11400-6

Park MJ, Park IC, Lee HC, Woo SH, Lee JY, Hong YJ, Rhee $\mathrm{CH}$, Lee YS, Lee SH, Shim BS, Kuroki T, Hong SI. Protein kinase $\mathrm{C}$-alpha activation by phorbol ester induces secretion of gelatinase B/MMP-9 through ERK $1 / 2$ pathway in capillary endothelial cells. Int J Oncol 2003;22:137-43

Park SH, Cho HN, Lee SJ, Kim TH, Lee Y, Park YM, Lee YJ, Cho CK, Yoo SY, Lee YS. Hsp25-induced radioresistance is associated with reduction of death by apoptosis: involvement of $\mathrm{Bcl} 2$ and the cell cycle. Radiat Res 2000; $54: 421-8$

Punnonen K, Denning M, Lee E, Li L, Phee SG, Yuspa SH. Keratinocyte differentiation is associated with changes in the expression and regulation of phosphlipase C isozyems. J Invest Dermatol 1993;101:719-26

Reynolds NJ, Baldassare JJ, Henderson PA, Shuler JL, Ballas LM, Burns DJ, Moonaw CR, Fisher GJ. Translocation and downregulation of protein kinase $C$ isoenzymes-alpha and -psilon by phorbol ester and bryostatin-1 in human keratinocytes and fibroblasts. J Invest Dermatol 1994;103: 64-9

Rice RH, Mehrpouyan M, O'Callahan W, Parenteau NL, Rubin AL. Keratinocyte transglutaminase: Differentiation marker and member of an extended family. Epithelial Cell Biol 1992;1:128-37

Sheu $H$, Kitajima $Y$, Yaoita $H$. Involvement of protein kianse $C$ in translocation of desmoplskins from cytosol to plasma membrane during desmosome formation in human squamouse cell carcinoma cells grown in low to normal calcium concentration. Exp Cell Res 1989;185:176-90

Tang W, Siboh VA, Isseroff $R$, Martinez D. Turnover of inositol phospholipids in cultured murine keratincoytes: Possible involvement of inositol triphosphate in cellular differentiation. J Invest Dermatol 1993;90:37-43

Wirth PJ, Yuspa SH, Thorgeirsson SS, Hennings H. Induction of common patterns of polypeptide synthesis and phosphorylation by calcium and 12-0-tetradecanoylphorbol13 -acetate in mouse epidermal cell culture. Cancer Res 1987;47:2831-38

Yuspa SH, Ben T, Hennings H, Lichti U. Divergent responses in epidermal basal cells exdposed to the promoter 12-0-tetradecanoylphorbol-13-acetate. Cancer Res 1982;42:2344-9

Yuspa SH, Ben T, Hennings $\mathrm{H}$. The induction of epidermal transglutaminase and terminal differentiation by tumor promoters in cultured epidermal cells. Carcinogenesis 1983;4: $1413-8$

Yuspa SH, Kilkenny AE, Steinert PM, Roop DR. Expression of murine epidermal differentiation makers is tightly regulated by restricted extracellular calcium concentrations in vitro. J Cell Biol 1989;109:1207-17

Yuspa SH, Henning $\mathrm{H}$, Tucker RW. The regulation of differentiation in normal and neoplastic keratinocytes. In: Howely P, Broker T (eds), Papillomaviruses. CLA symposia and Molecular and Cellular Biology, New Series. 1990, 211-22 Alan R. Lies, Inc., New York 